\title{
OPEN Adaptive ecological niche migration does not negate extinction susceptibility
}

\begin{abstract}
A. Woodhouse ${ }^{1 凶}$, S. L. Jackson ${ }^{1}$, R. A. Jamieson ${ }^{1}$, R. J. Newton ${ }^{1}$, P. F. Sexton ${ }^{2}$ \& T. Aze ${ }^{1}$
Extinction rates in the modern world are currently at their highest in 66 million years and are likely to increase with projections of future climate change. Our knowledge of modern-day extinction risk is largely limited to decadal-centennial terrestrial records, while data from the marine realm is typically applied to high-order ( $>1$ million year) timescales. At present, it is unclear whether fossil organisms with common ancestry and ecological niche exhibit consistent indicators of ecological stress prior to extinction. The marine microfossil record, specifically that of the planktonic foraminifera, allows for high-resolution analyses of large numbers of fossil individuals with incredibly well-established ecological and phylogenetic history. Here, analysis of the isochronous extinction of two members of the planktonic foraminiferal genus Dentoglobigerina shows disruptive selection differentially compounded by permanent ecological niche migration, "pre-extinction gigantism", and photosymbiont bleaching prior to extinction. Despite shared ecological and phylogenetic affinity, and timing of extinction, the marked discrepancies observed within the pre-extinction phenotypic responses are species-specific. These behaviours may provide insights into the nature of evolution and extinction in the open ocean and can potentially assist in the recognition and understanding of marine extinction risk in response to global climate change.
\end{abstract}

Current extinction rates are estimated to be at least eight times higher than the background Cenozoic ( $<66 \mathrm{Ma})$ average $^{1}$ and understanding the impacts of rapid climate change on global biodiversity is of critical importance for creating a sustainable future (https://sdgs.un.org/goals). An increasing body of evidence suggests climate state variability is potentially more important than the direction of temperature change with respect to heightened extinction rates ${ }^{2,3}$. As such, we look to the Cenozoic marine sedimentary record, which allows us to assess the impacts of high variability in climate state on extinct biodiversity ${ }^{4,5}$. In this study, we focus on the planktonic foraminifera, single-celled marine protists with a global distribution and the most complete Cenozoic specieslevel fossil record ${ }^{6}$. Their calcareous skeletons, or tests, preserve not only their entire life history, but also a biogeochemical expression of the surrounding water column (e.g., ${ }^{7}$ ). These features allow for high-resolution species-specific quantification of physiological and ecological adaptation through periods of climate variability (e.g., $\left.{ }^{8-21}\right)$.

Our analysis investigates the response of the planktonic foraminiferal genus Dentoglobigerina, of which two species (Dentoglobigerina altispira and Dentoglobigerina baroemoenensis) undergo an isochronous extinction at $\sim 3.04 \mathrm{Ma}$, during a period associated with increasing climate state variability ${ }^{22,23}$. Through high-resolution $(\sim$ $5 \mathrm{kyr}$ ) paired morphometric and geochemical analyses, we demonstrate that despite the two species occupying the same ecological niche space and sharing close phylogenetic affinity, they exhibit species-specific ecological and morphological responses prior to extinction.

Morphological data enables the assessment of the relationship between body size and shape parameters likely to record long- and short-term morphometric trends in response to global climate ${ }^{14}$ (see Methods for designation of size and shape parameters). Single-specimen planktonic foraminiferal geochemical records allow us to place species within discrete ecological niches or "ecogroups" $\left(\mathrm{see}^{6}\right)$, wherein the investigation of stable oxygen $\left(\delta^{18} \mathrm{O}\right)$ and carbon $\left(\delta^{13} \mathrm{C}\right)$ isotope ratios can be used to determine the relative degree of bathymetric and ecological separation within extant and extinct species ${ }^{7,24}$.

The methods and hypotheses tested in this study highlight the utility of the marine micropaleontological record in assessing the pre-extinction ecological response of organisms at high-resolution during intervals of global climate variability.

${ }^{1}$ School of Earth and Environment, University of Leeds, Leeds LS2 9JT, UK. ${ }^{2}$ School of Environment, Earth and Ecosystem Sciences, Open University, Walton Hall, Kents Hill, Milton Keynes MK7 6AA, UK.『email: eeadw@ leeds.ac.uk 


\begin{abstract}
Results
Morphological records. There is a long-term ( $\sim 400 \mathrm{kyr})$ morphological trend approaching the dentoglobigerinid extinction interval $(\sim 3.038 \mathrm{Ma})$, where both species demonstrate a general increase in body size and range (Fig. 1). At $\sim 3.071 \mathrm{Ma}$ (Fig. 1), $30 \mathrm{kyrs}$ prior to the extinction of $D$. altispira, mean shape parameters indicate a deviation from relative morphological uniformity (Fig. S1), whereby the relationship between test area and aspect ratio (Fig. 2a) shows distinct changes due to a marked decrease in mean test area (Fig. 1a). This morphological excursion ends $10 \mathrm{kyrs}$ later $(3.061 \mathrm{Ma})$, where the size/shape values return to background values that were more typical prior to $\sim 3.071 \mathrm{Ma}$ (Figs. 1,2). We designate the respective sedimentary intervals preceding and succeeding these two morphological events to signify distinct ecological "Phases" in dentoglobigerinid pre-extinction response, herein termed "Phase 1" and "Phase 2", respectively. Additionally, the 10 kyr interval encompassed by the two Phases is deemed to represent a "Phase Transition" (Fig. 1).

Within D. baroemoenensis, the size/shape relationship generally tends to show higher inter-sample variability than D. altispira throughout the record (Figs. 1,2). However, the most significant changes are seen following the Phase Transition, where there is marked increase in mean test size through the final $\sim 10 \mathrm{kyrs}$ prior to extinction (Figs. 1, 2).
\end{abstract}

Geochemical records. Generally, dentoglobigerinid specimens exhibit stable isotope values typical of modern symbiont-hosting surface mixed-layer dwellers ${ }^{24}$ (Fig. 3, SI), with high $\delta^{13} \mathrm{C}$ and low $\delta^{18} \mathrm{O}$, respectively. At $\sim 3.061 \mathrm{Ma}$, contemporaneous with the initiation of Phase 2 (Figs. 1, 2), D. altispira $\delta^{13} \mathrm{C}$ and $\delta^{18} \mathrm{O}$ signals exhibit significant, permanent negative and positive shifts, respectively, to values more consistent with species living in the subsurface, rather than the surface mixed-layer (Fig. 1i, j). This signal is not reflected by D. baroemoenensis at this time, and it is only in the final sample prior to extinction $(\sim 3.038 \mathrm{Ma})$ that a substantial negative $\delta^{13} \mathrm{C}$, and positive $\delta^{18} \mathrm{O}$ excursion consistent with the occupation of a deeper living-depth is seen in this species (Fig. 1i, j).

Statistical analyses. Our data and linear models (see SI, Tables S1-4) identify trends in dentoglobigerinid morphology and ecology that support the designation of distinct ecological "Phases" in the final 30 kyrs of our Dentoglobigerina species. Phase 1 is typified by stable morphological and geochemical background conditions from 3.466-3.071 Ma (Figs. 1, 2). At this point the Phase Transition commences, identified by the morphological excursion of $D$. altispira (Figs. 1,2). Finally, $10 \mathrm{kyr}$ later Phase 2 initiates, marked by the coeval end of the period of diminished size in D. altispira, and the geochemical excursion representing a shift in its ecological niche (Figs. 1, 2, 3). For D. baroemoenensis, samples sourced from the Phase Transition are notably lacking in specimens, and enhanced size increase and morphological stochasticity is observed through much of Phase 2 , (Figs. 1, 2).

Models tested whether the abiotic conditions of the paleo-water column (signified by the stable isotopic signature of the present extant species with known living depths ${ }^{6,24}$ ), responded in or out of tandem with the dentoglobigerinid signature. Throughout Phase 1 the dentoglobigerinids have isotopic signals that are consistent with a surface mixed-layer species which hosts photosymbiotic algae ${ }^{6,24}$ (Figs. 1, 3) and the two dentoglobigerinid species $\delta^{18} \mathrm{O}$ signals respond in tandem (Tables S1 \& S2). In Phase 2, there is a marked decoupling in the $\delta^{13} \mathrm{C}$ signal of the two species (Tables S3 \& S4) potentially indicating a disruption of photosymbiosis for D. altispira, but not for $D$. baroemoenensis, which maintains its ecological affinity up to the sample preceding extinction (Fig. 1i, j). Additional linear models testing the relationship between dentoglobigerinid morphology and environment show that as bottom water $\delta^{18} \mathrm{O}$ becomes more positive and $\delta^{13} \mathrm{C}$ more negative (e.g., as mean global temperature decreases/ice extent increases) dentoglobigerinid test area increases throughout Phase 1 (Tables S1 \& S2). However, for D. altispira, this signal is lost in Phase 2, and for D. baroemoenensis the signal switches to increased test area mirroring more negative bottom-water $\delta^{18} \mathrm{O}$ (Tables S3 \& S4).

Grubbs' test ${ }^{25}$ results (Table 1) indicate that outlier samples with statistical significance tend to be grouped within either the Phase Transition or Phase 2 for D. altispira, whereas all significant $D$. baroemoenensis outliers are represented by the final sample. Mann-Whitney $U$ test ${ }^{26}$ results (Table 2) show a significant difference between the $D$. altispira $\delta^{13} \mathrm{C}$ signal of Phases 1 and 2 . For $D$. baroemoenensis, Mann-Whitney $\mathrm{U}$ and $\mathrm{z}$-test results (Table 2) indicate that the $\delta^{18} \mathrm{O}$ signature, and the umbilical and lateral test area and size range records are significantly different between the two phases.

\title{
Discussion
}

The Cenozoic planktonic foraminiferal fossil record documents a strong positive correlation between test size and the degree of global marine latitudinal and vertical temperature gradients ${ }^{22,27}$, however the largest intraspecific test sizes tend not to be analogous with species' ecological optima ${ }^{28,29}$. In Phase 1, dentoglobigerinid test size data shows a gradual relative increase through time (Figs. 1; S1) likely representing a response to the development of temperature gradients associated with the intensification of northern hemisphere icesheets ${ }^{22,23}$. At the initiation of the Phase Transition ( $3.071 \mathrm{Ma})$ stepwise disruptions in both morphology and geochemical signatures are likely indicative of disruptive selection and "bet-hedging"30,31, a typical response to the propagation of terminal stress levels preceding extinction ${ }^{32,33}$. Previous studies ${ }^{15,16}$ document increasing growth asymmetry and morphological trait variance as responses to abiotic forcing, wherein species produce offspring with high inter-individual phenotypic variability during unfavourable environmental conditions to improve mean population fitness ${ }^{15,34-36}$.

In the case of D. altispira, the ecological end-result following the Phase Transition approaching the termination of the record appears to be permanent ecological niche migration from the surface mixed-layer down to the subsurface, supported by Mann-Whitney $U$ test results (Table 2) on $\delta^{13} \mathrm{C}$ signals between Phases 1 and 2 (Figs. 1, 3). Significantly, D. baroemoenensis displays an almost total absence during the Phase Transition (Fig. 1), 


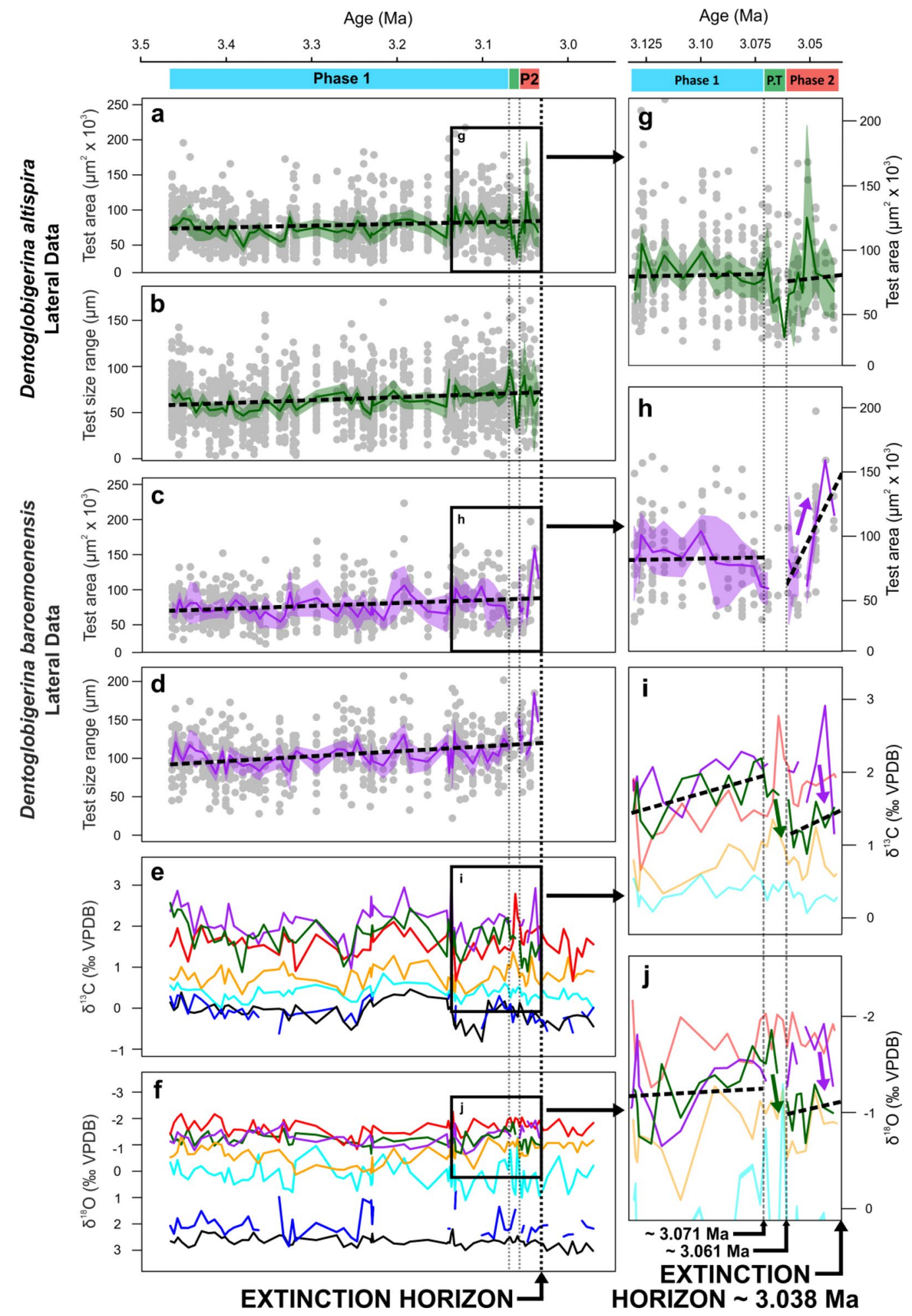

Figure 1. Stratigraphic log of Hole U1338A with geochemical and biotic records through dentoglobigerinid extinction event. (a) D. altispira Area, (b) and size range, (c) D. baroemoenensis Area, (d) and size range, (e) Single and multi-specimens planktonic foraminiferal $\delta^{13} \mathrm{C}$, (f) Single and multi-specimen planktonic foraminiferal $\delta^{18} \mathrm{O},(\mathbf{g}-\mathbf{j})$ blown up dentoglobigerinid Area, and isotope data in pre-extinction interval. Black $=$ bottom -water, dark blue $=$ subthermocline, cyan $=$ thermocline, orange $=$ subsurface, red $=$ surface mixed layer, green $=$ D. altispira, purple $=D$. baroemoenensis. Solid coloured lines for dentoglobigerinids are mean values of multiple single specimen analyses, shaded areas are $95 \%$ confidence intervals, black dashed lines are species trendlines, light vertical dotted lines indicate boundaries between "Phases", black vertical dotted line indicates extinction horizon. P2 Phase 2, P.T Phase Transition. 


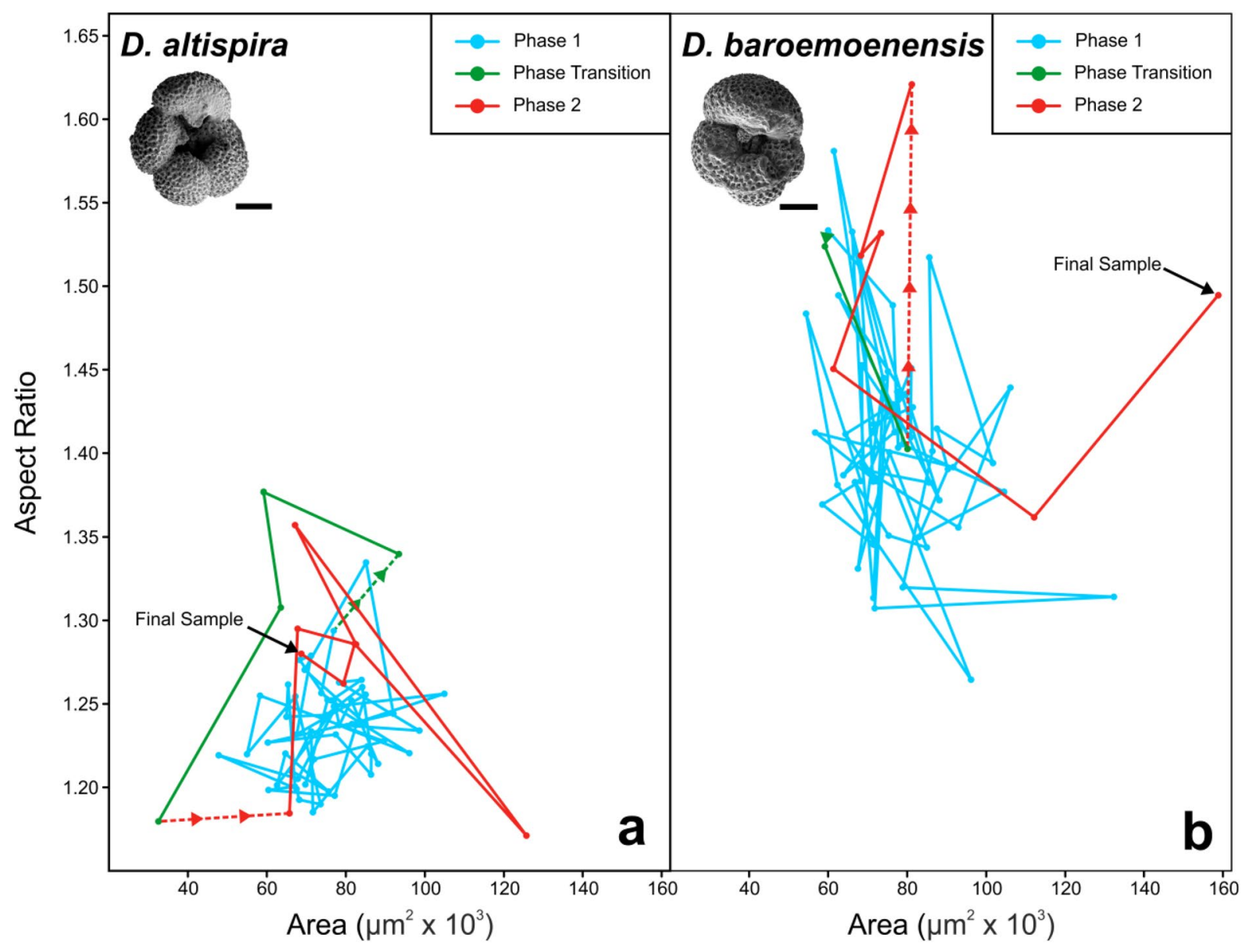

Figure 2. Sample means of lateral area and aspect ratio of (a) D. altispira, and (b) D. baroemoenensis. Blue $=$ Phase 1 , green $=$ Phase Transition, Red $=$ Phase 2. Initiation of the phase transition is defined by the excursion in D. altispira morphometric data (see "Morphological Records"). Initiation of Phase 2 is defined $D$. altispira morphometric data returning to Phase 1 variability (see "Morphological Records"), and additionally by geochemical excursions in D. altispira stable isotope data (see "Geochemical Records", Fig. 1). Scale bars $=100 \mu \mathrm{m}$.

supporting the prevalence of environmental conditions detrimental to dentoglobigerinid ecology. Upon its return, it shows a dramatic increase in lateral and umbilical area (Figs. 1; S1), where Mann-Whitney U test and z-test results indicate significantly different body size and range to Phase 1 (Table 2). These changes, which we term "pre-extinction gigantism", are antithetical to the "pre-extinction dwarfing"10,37 previously documented in several other species, and may represent a response to the steepening of vertical and latitudinal water column temperature gradients associated with cryosphere development ${ }^{22,23}$, typified by more distinct spacing between the geochemically assigned ecological habits during Phase 2 (Fig. 3).

The minor general trend of increasing body size range in both species (Fig. 1a, c) potentially infers long-term mitigation of external environmental pressures expressed through rising polymorphism. Further research is required; however, such behaviour may be characteristic of temporally long ranging species ${ }^{38}$ when subjected to global climate state variations which deviate far from their ancestral ecosystem ${ }^{39,40}$.

The study species share close phylogenetic and ecological affinity ${ }^{38}$, maintain high-order morphological likeness from speciation, and undergo isochronous extinction, yet the phenotypic responses recorded prior to extinction are species-specific. Rapid within-clade character change, cladogenesis, and extinction during periods of detrimental environmental change are likely common-place within the history of life ${ }^{32}$, and phylogenetically and ecologically adjacent taxa can exhibit similarities in selection pressures which do not necessarily trigger an adaptive response in the same direction ${ }^{32,33,39}$.

For $D$. altispira, migration from the surface mixed layer to the subsurface may be compounded either by a photosymbiont reduction/suppression ${ }^{18}$, or adoption of a facultative symbiotic ecological strategy, recognized to enhance flexibility of nutritional sources through minimal energetic investment ${ }^{41,42}$. This proposed adaptation is suggested over total algal photosymbiont "bleaching", $11,18,21,43$, as D. altispira continues to present $\delta^{13} \mathrm{C}$ enrichment higher than values observed in the asymbiotic, subsurface-dwelling taxa analysed in this study ${ }^{42}$, yet similar $\delta^{18} \mathrm{O}$ values (Figs. 1, 3).

For $D$. baroemoenensis, water column temperature gradient dynamics associated with thermocline shallowing ${ }^{22,44}$ are a potential trigger for the brief vacation and apparent "pre-extinction gigantism" exhibited 


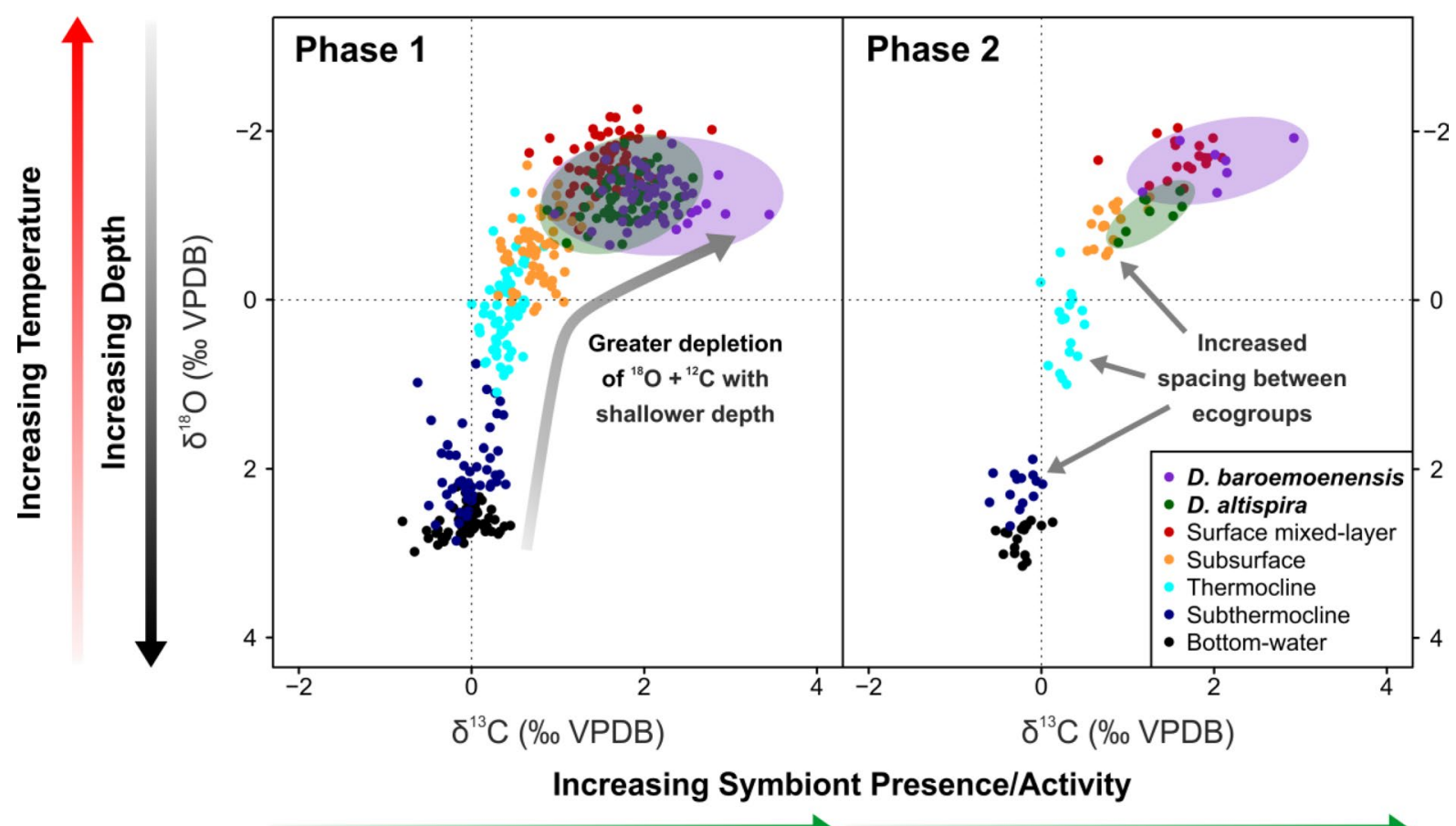

Figure 3. $\delta^{13} \mathrm{C}$ and $\delta^{18} \mathrm{O}$ cross-plots through Phase 1 and Phase 2. Black=Bottom-water, dark blue $=$ subthermocline, cyan $=$ thermocline, orange $=$ subsurface, red $=$ surface mixed layer, green $=D$. altispira, purple $=D$. baroemoenensis. Dentoglobigerina measurements are single specimens, others are multiple specimens.

\begin{tabular}{|l|c|l|l|l|}
\hline Parameter & D. altispira & Position & D. baroemoenensis & Position \\
\hline Carbon & 0.5492 & Within P1 & 0.07428 & Within P1 \\
\hline Oxygen & 0.2239 & Within PT & 0.7708 & Within P2 \\
\hline U_Area & $<\boldsymbol{0 . 0 1}$ & Within P2 & $<\boldsymbol{0 . 0 1}$ & Final sample \\
\hline U_Aspect Ratio & 0.1084 & Within PT & 0.09192 & 1st PT sample \\
\hline U_Dmax & 0.07362 & Within P2 & $<\boldsymbol{0 . 0 1}$ & Final sample \\
\hline U_Dmin & $<\boldsymbol{0 . 0 5}$ & Within P2 & $<\boldsymbol{0 . 0 5}$ & Final sample \\
\hline U_Range & 0.2757 & Within P1 & 0.1778 & Within P2 \\
\hline U_Roundness & $<\boldsymbol{0 . 0 5}$ & Within P1 & NA & NA \\
\hline U_Circularity & 0.2506 & 1st PT sample & NA & NA \\
\hline L_Area & $<\boldsymbol{0 . 0 1}$ & Within P2 & 0.06507 & Final sample \\
\hline L_Aspect_Ratio & $<\boldsymbol{0 . 0 5}$ & Within PT & 0.06467 & 1st P2 sample \\
\hline L_Dmax & 0.05313 & Within P2 & $<\boldsymbol{0 . 0 5}$ & Final sample \\
\hline L_Dmin & $<\boldsymbol{0 . 0 1}$ & Within P2 & 0.264 & Penultimate sample \\
\hline L_Range & 0.06445 & 1st PT sample & 0.08086 & 1st P2 sample \\
\hline L_Roundness & $<\boldsymbol{0 . 0 5}$ & Last $\boldsymbol{P T}$ sample & NA & NA \\
\hline L_Circularity & 0.562 & Within P2 & NA & NA \\
\hline
\end{tabular}

Table 1. Grubbs' Test results. Bold and italic results indicate statistical significance $(\mathrm{p}<0.05)$. U, Umbilical; $\mathrm{L}$, Lateral; P1, Phase 1; P2, Phase 2; PT, Phase Transition.

through Phase 2 . The final sample of this species' record may be marked by symbiont bleaching wherein, despite a size increase, specimens exhibit a reduction in $\delta^{13} \mathrm{C}$ values (Fig. 1). Alternatively, D. baroemoenensis may also be recording rapid migration down to the subsurface, or a significant change in the extent of test calcification just prior to extinction ${ }^{24,45,46}$.

Photosymbiont bleaching driven by extreme heat stress has been recorded in extant groups such as corals ${ }^{47}$ and larger benthic foraminifera ${ }^{48,49}$, and previously, records of the potential bleaching of algal photosymbionts within fossil planktonic foraminifera have been confined to early Cenozoic hyperthermals (e.g., ${ }^{9,11,18,21,43}$ ). Despite bleaching amongst modern corals being primarily driven by increasing temperature ${ }^{47,50,51}$, a multitude of environmental stressors are associated with bleaching responses ${ }^{52,53}$, and the prospective bleaching of $D$. 


\begin{tabular}{|c|c|c|c|c|}
\hline \multirow[b]{2}{*}{ Parameter } & \multicolumn{2}{|c|}{ D. altispira } & \multicolumn{2}{|c|}{$\begin{array}{l}\text { D. } \\
\text { baroemoenensis }\end{array}$} \\
\hline & Test & P1vP2 & Test & P1vP2 \\
\hline Carbon & $M-W U$ & $<0.01$ & z-test & 0.655 \\
\hline Oxygen & M-WU & 0.183 & z-test & $<0.01$ \\
\hline U_Area & M-WU & 0.227 & M-WU & $<0.01$ \\
\hline U_Aspect_Ratio & M-WU & 0.806 & M-WU & 0.243 \\
\hline U_Size_Range & M-WU & 0.557 & M-WU & $<0.01$ \\
\hline U_Roundness & M-WU & 0.135 & NA & NA \\
\hline U_Circularity & M-WU & 0.937 & NA & NA \\
\hline L_Area & M-WU & 0.429 & M-WU & $<0.01$ \\
\hline L_Aspect_Ratio & M-WU & 0.272 & z-test & 0.476 \\
\hline L_Size_Range & M-WU & 0.227 & z-test & $<0.01$ \\
\hline L_Roundness & M-WU & 0.506 & NA & NA \\
\hline L_Circularity & M-WU & 0.176 & NA & NA \\
\hline
\end{tabular}

Table 2. Mann-Whitney $U$ test results for between $D$. altispira and D. baroemoenensis phase populations. Bold, italic results indicate statistical significance $(\mathrm{p}<0.05)$. U, Umbilical; L, Lateral; P1, Phase 1; P2, Phase 2.

baroemoenensis may indicate that this pre-extinction response in symbiont-bearing taxa may be more common than previously thought during intervals not characterised by elevated temperatures.

Model results (Tables S1-4) lend further support to our interpretations, in which both morphological and ecological responses display discrete signatures between phases, characteristic of disruptive selection ${ }^{30,31}$. The interpreted behaviour of these organisms raises some interesting questions. One of the most pressing and fundamental issues for palaeoceanography, is whether fossil organisms identified via their external morphology which are used for the inference of paleoclimatic data maintain ecological uniformitarianism for the entirety of their stratigraphic range. Our study, alongside other novel research on modern and fossil populations ${ }^{18,54-63}$ suggests not, and as such deriving environmental interpretations from fossil taxa, particularly during intervals of climate variability, should be treated with caution. Whether the documentation of these behaviours indicate failed efforts at stress mitigation via water-depth associated parapatric anagenesis is currently undetermined, but further high-resolution comparable investigations through speciation events may help to understand the fundamental mechanisms driving evolution and extinction in an ecosystem with limited vicariance potential such as the open ocean.

\section{Summary}

The studied section exhibits a high-resolution record of the pre-extinction biotic response of two members of the planktonic foraminiferal genus Dentoglobigerina during major global palaeoceanographic changes associated with the development of northern hemisphere ice sheet formation. Despite the species' phylogenetic and ecological affinities, documented phenotypic responses are species-specific, wherein both D. altispira and $D$. baroemoenensis exhibit evidence of permanent adaptive ecological niche migration and photosymbiont reduction. In addition, D. baroemoenensis documents "pre-extinction gigantism", and potential photosymbiont bleaching. This study highlights the importance of high-resolution analyses when investigating biological responses and extinction dynamics. The unparalleled resolution of the marine microfossil record allows us to identify and evaluate past occurrences of morpho-ecological stochasticity indicative of disruptive selection and niche adaptation. However more comprehensive studies utilising multiple localities are required to improve our understanding and identification of the potential for pre-extinction signals to better recognise extinction risk in response to rapid climate change.

\section{Methods}

Site selection. Material was sourced from Integrated Ocean Drilling Program Expedition 321 Site U1338 (Hole 1338A) $\left(2^{\circ} 30.469^{\prime} \mathrm{N}, 17^{\circ} 58.162^{\prime} \mathrm{W}\right)$ situated in the East Equatorial Pacific, which was drilled to $410.0 \mathrm{mbsf}$ through Holocene-early Miocene pelagic sediments ${ }^{64}$. At $\sim 3 \mathrm{Ma}$, the site was in a deep-water pelagic environment of similar water depth and paleolatitude ${ }^{65}$ to the modern. The primary lithologies represented are calcareous, diatom and radiolarian nannofossil oozes and chalks. Despite the deep-water settings and primarily calcareous nature of the sediments, excellent microfossil preservation has been recorded throughout this core interval ${ }^{66}$. A preliminary assessment of core U1338A was carried out to determine the approximate position of the extinction of the dentoglobigerinids ( $3 \mathrm{Ma}$ ) based on tropical biostratigraphy ${ }^{67}$, and shipboard paleomagnetic data ${ }^{64}$.

Assemblage analysis. Sediment volumes of 20-40 cc were collected and washed with de-ionised water over a $63-\mu \mathrm{m}$ sieve; the residues were dried in an oven at $40{ }^{\circ} \mathrm{C}$ and split. All samples were examined using a Zeiss Stemi 305 Compact Stereo Microscope. We identified planktonic foraminifers following the taxonomy of Kennett and Srinivasan ${ }^{68}$, Schiebel and Hemleben ${ }^{27}$, and Wade et al. ${ }^{38}$ and performed assemblage counts on 300 individuals from $>63 \mu \mathrm{m}$ splits. 
Chronology determination. During sampling of the extinction interval and identification of the dentoglobigerinid extinction event, specimens of Cibicidoides wuellerstorfi were also picked to create a benthic foraminiferal $\delta^{18} \mathrm{O}$ record. This record was constructed and tuned to the Ocean Drilling Program Site 849/IODP Site 1338 stack constructed by Lyle et al. ${ }^{69}$ using QAnalySeries software ${ }^{70}$ to better constrain the timing of preextinction responses compared to using palaeomagnetic data alone.

Morphometrics and repeatability. The first 50 (where present) complete specimens of the genus Dentoglobigerina were picked and mounted in umbilical position on card slides pierced with a fine needle to accommodate the variably spired nature of species in the genus ${ }^{38}$. Specimens were imaged umbilically using a Zeiss Axio Zoom V16 microscope with attached Canon EOS 100D camera at $\times 19.4$ magnification. All specimens were then rotated $90^{\circ}$ laterally, and imaged whilst propped onto their penultimate chamber. Images were processed using the image analysis software Image Pro Premier, and the "size" trait parameters: test area (Area, $\mu \mathrm{m}^{2}$ ), and test size range (minimum test diameter (Dmin)-maximum test diameter (Dmax)), and "shape" trait parameters: aspect ratio (AR, ratio between maximum test height and width), roundness (perimeter ${ }^{2}(\mu \mathrm{m}) / 4 \pi$.test area), and circularity (4.test area)/( $\pi$.MaxFeret ${ }^{2}$ ), were captured from both orientations, extracted, and databased (see SI). To determine whether the size and shape parameters were repeatably valid measurements, trait repeatability ${ }^{71,72}$ was performed by removing, remounting, and reimaging 200 specimens of each analysed dentoglobigerinid species (100 umbilical orientations, and 100 lateral). Measurements of the repeated runs (Fig. S2) are plotted using continuous frequency distributions (kernel density estimates with a Gaussian kernel and bandwidth $h=1.06^{*} s n^{1 / 5}$ following Silverman ${ }^{73}$, with $s$ the standard deviation of trait measurements per species and $n$ the number of analysed individuals). Results were evaluated through Wilcoxon signed-rank test using R software ${ }^{74}$. Where mean run rank differences deviated significantly, measured traits were deemed non-repeatable (Fig. S3). All measured size and shape trait parameters were deemed repeatable for $D$. altispira, whereas for $D$. baroemoenensis, roundness and circularity were not repeatable, and were subsequently removed from further interpretations. Repeatable traits were then subjected to power analysis ${ }^{75}$ using the 'pwr' package in $\mathrm{R}^{76}$ to determine the minimum number of individuals required to detect mean sample trait changes of $5,10,15,20,25$, and $30 \%$ with power $>0.9$ and a significance level of $\mathrm{p}=0.01$ as suggested by Brombacher et al. ${ }^{71}$ (Fig. S4; Table S5).

Stable isotope analysis. For stable isotope analysis, species-specific size fractions were screened and picked for exceptionally preserved specimens of Dentoglobigerina altispira $(>200 \mu \mathrm{m})$, and Dentoglobigerina baroemoenensis $(>200 \mu \mathrm{m})$ exhibiting "excellent" and "glassy" preservation ${ }^{77}$. The same screening process was performed for nominate taxa representing specific ecological habits through the water column: Globigerinoides ruber (212-350 $\mu \mathrm{m}$, surface mixed-layer), Neogloboquadrina incompta (212-350 $\mu \mathrm{m}$, subsurface), Globorotalia tumida $\left(>300 \mu \mathrm{m}\right.$, thermocline/photic zone base, corrected for a $1.0 \% \delta^{13} \mathrm{C}$ enrichment due to this species occupying the shallow oxygen minimum zone and consequential effects of reduced ambient $\left.\mathrm{pH}^{24}\right)$, Hirsutella scitula (212-300 $\mu \mathrm{m}$, subthermocline), and Cibicidoides wuellerstorfi $\left(>212 \mu \mathrm{m}\right.$, bottom-water) (see $\left.\mathrm{e}^{6,24,78,79}\right)$. Single specimens of dentoglobigerinids, and multiple specimens of all other foraminifer species were analysed using an Elementar IsoPrime Dual-Inlet Isotope Ratio Mass Spectrometer in the Cohen Geochemistry Laboratory, University of Leeds, and data are reported to the Vienna Pee Dee belemnite (VPDB) scale using an Elemental Microanalysis Carrera marble standard where analytical precision was better than 0.07 and $0.13 \%$ for $\delta^{13} \mathrm{C}$ and $\delta^{18} \mathrm{O}$ (1 standard deviation), respectively (Figs. 1, 3; see SI).

Statistical analysis. Prior to statistical modelling, all sample mean isotopic and morphometric measurements were log standardised and the sample first differences generated per time step. All statistical analyses and linear modelling were carried out using $\mathrm{R}$ software ${ }^{74}$. For linear models, statistically significant relationships were identified between variables, and residual standard mean errors (RSE) were calculated to determine the model fit (Tables S3 \& S4). The normality of dentoglobigerinid morphometric and geochemical parameter data was assessed using a Shapiro-Wilk test ${ }^{80}$ to determine whether parametric or non-parametric tests were applicable. Dentoglobigerinid sample-mean morphological and geochemical parameters were tested to identify study section outliers through Grubb's test ${ }^{25}$ using the 'outliers' package ${ }^{81}$. Comparisons between all dentoglobigerinid morphological and geochemical parameters between the two phases (i.e., specimens before and after the defined Phase Transition) were performed by Mann-Whitney $\mathrm{U}^{26}$ using the 'asht' package ${ }^{82}$, and $z$-tests using the 'BDSA' package $^{83}$.

Received: 5 April 2021; Accepted: 29 June 2021

Published online: 29 July 2021

\section{References}

1. Ceballos, G. et al. Accelerated modern human-induced species losses: Entering the sixth mass extinction. Sci. Adv. https://doi.org/ 10.1126/sciadv.1400253 (2015).

2. Edie, S. M., Huang, S., Collins, K. S., Roy, K. \& Jablonski, D. Loss of biodiversity dimensions through shifting climates and ancient mass extinctions. Integr. Comp. Biol. 58, 1179-1190. https://doi.org/10.1093/icb/icy111 (2018).

3. Pinsky, M. L., Eikeset, A. M., McCauley, D. J., Payne, J. L. \& Sunday, J. M. Greater vulnerability to warming of marine versus terrestrial ectotherms. Nature 569, 108-111. https://doi.org/10.1038/S51586-019-1132-4 (2019).

4. Ezard, T. H. G., Aze, T., Pearson, P. N. \& Purvis, A. Interplay between changing climate and species' ecology drives macroevolutionary dynamics. Science 332, 349-351. https://doi.org/10.1126/science.1203060 (2011). 
5. Smits, P. \& Finnegan, S. How predictable is extinction? Forecasting species survival at million-year timescales. Philos. Trans. $R$. Soc. B Biol. Sci. 374, 1. https://doi.org/10.1098/rstb.2019.0392 (2019).

6. Aze, T. et al. A phylogeny of Cenozoic macroperforate planktonic foraminifera from fossil data. Biol. Rev. 86, 900-927. https:// doi.org/10.1111/j.1469-185X.2011.00178.x (2011).

7. Edgar, K. M., Hull, P. M. \& Ezard, T. H. G. Evolutionary history biases inferences of ecology and environment from $\delta^{13} \mathrm{C}$ but not $\delta^{18} \mathrm{O}$ values. Nat. Commun. 8, 1106. https://doi.org/10.1038/s41467-017-01154-7 (2017).

8. Knappertsbusch, M. Morphological variability of Globorotalia menardii (planktonic foraminifera) in two DSDP cores from the Caribbean Sea and the Eastern Equatorial Pacific. Carnets de Géologie/Notebooks Geol. CG2007 1-34. https://doi.org/10.4267/ 2042/8455 (2007).

9. Wade, B. S., Al-Sabouni, N., Hemleben, C. \& Kroon, D. Symbiont bleaching in fossil planktonic foraminifera. Evol. Ecol. 22, 253-265. https://doi.org/10.1007/s10682-007-9176-6 (2008).

10. Wade, B. S. \& Olsson, R. K. Investigation of pre-extinction dwarfing in Cenozoic planktonic foraminifera. Palaeogeogr. Palaeoclimatol. Palaeoecol. 284, 39-46. https://doi.org/10.1016/j.palaeo.2009.08.026 (2009).

11. Edgar, K. M. et al. Symbiont 'bleaching' in planktic foraminifera during the Middle Eocene climatic optimum. Geology 41, 15-18. https://doi.org/10.1130/G33388.1 (2013).

12. Pearson, P. N. \& Ezard, T. H. G. Evolution and speciation in the Eocene planktonic foraminifer Turborotalia. Paleobiology 40, 130-143. https://doi.org/10.1666/13004 (2014).

13. Wade, B. S., Poole, C. R. \& Boyd, J. L. Giantism in Oligocene planktonic foraminifera Paragloborotalia opima: Morphometric constraints from the equatorial Pacific Ocean. Newsl. Stratigr. 49, 421-444. https://doi.org/10.1127/nos/2016/0270 (2016).

14. Brombacher, A., Wilson, P. A., Bailey, I. \& Ezard, T. H. G. The breakdown of static and evolutionary allometries during climatic upheaval. Am. Nat. https://doi.org/10.5061/dryad.8jf2k (2017).

15. Weinkauf, M. F. G., Moller, T., Koch, M. C. \& Kučera, M. Disruptive selection and bet-hedging in planktonic Foraminifera: Shell morphology as predictor of extinctions. Front. Ecol. Evol. https://doi.org/10.3389/fevo.2014.00064 (2014).

16. Weinkauf, M. F. G., Bonitz, F. G. W., Martini, R. \& Kučera, M. An extinction event in planktonic Foraminifera preceded by stabilizing selection. PLoS ONE 14, 1-21. https://doi.org/10.1371/journal.pone.0223490 (2019).

17. Falzioni, F., Petrizzo, M. R. \& Valagussa, M. A morphometric methodology to assess planktonic foraminiferal response to environmental perturbations: The case study of Oceanic Anoxic Event 2, Late Cretaceous. Bollettino della Società Paleontologica Italiana 57, 103-124. https://doi.org/10.4435/BSPI.2018.07 (2018).

18. Si, W. \& Aubry, M. P. Vital effects and ecologic adaptation of photosymbiont-bearing planktonic foraminifera during the PaleoceneEocene thermal maximum, implications for paleoclimate. Paleoceanogr. Paleoclimatol. 33, 112-125. https://doi.org/10.1002/2017P A003219 (2018).

19. Fox, L. R., Stukins, S., Hill, T. \& Miller, G. Quantifying the effect of anthropogenic climate change on calcifying plankton. Sci. Rep. 10, 1620. https://doi.org/10.1038/s41598-020-58501-w (2020).

20. Todd, C. L., Schmidt, D. N., Robinson, M. M. \& De Schepper, S. Planktonic foraminiferal test size and weight response to the late Pliocene environment. Paleoceanogr. Paleoclimatol. https://doi.org/10.1029/2019PA003738 (2020).

21. Shaw, J. O. et al. Photosymbiosis in planktonic foraminifera across the Paleocene-Eocene thermal maximum. Paleobiology https:// doi.org/10.1017/pab.2021.7 (2021).

22. Schmidt, D. N., Thierstein, H. R. \& Bollmann, J. The evolutionary history of size variation of planktic foraminiferal assemblages in the Cenozoic. Palaeogeogr. Palaeoclimatol. Palaeoecol. 212, 159-180. https://doi.org/10.1016/j.palaeo.2004.06.002 (2004).

23. Brierley, C. M. \& Fedorov, A. V. Relative importance of meridional and zonal sea surface temperature gradients for the onset of the ice ages and Pliocene-Pleistocene climate evolution. Paleoceanogr. Paleoclimatol. 25, 1-16. https://doi.org/10.1029/2009PA0018 09 (2010).

24. Birch, H., Coxall, H. K., Pearson, P. N., Kroon, D. \& O’Regan, M. Planktonic foraminifera stable isotopes and water column structure: Disentangling ecological signals. Mar. Micropaleontol. 101, 127-145. https://doi.org/10.1016/j.marmicro.2013.02.002 (2013).

25. Grubbs, F. Procedures for detecting outlying observations in samples. Technometrics 11, 1-21. https://doi.org/10.1080/00401706. 1969.10490657 (1969).

26. Mann, H. B. \& Whitney, D. R. On a test of whether one of two random variables is stochastically larger than the other. Ann. Math. Stat. 18, 50-60. https://doi.org/10.1214/aoms/1177730491 (1947).

27. Schiebel, R. \& Hemleben, C. Planktic Foraminifers in the Modern Ocean 1-350 (Springer, 2017). https://doi.org/10.1007/978-366250297-6.

28. Schmidt, D. N., Thierstein, H. R., Bollmann, J. \& Schiebel, R. Abiotic forcing of plankton evolution in the Cenozoic. Science 303, 207-210. https://doi.org/10.1126/science.1090592 (2004).

29. Rillo, M., Miller, G., Kučera, M. \& Ezard, T. Predictability of intraspecific size variation in extant planktonic foraminifera. BioRxiv https://doi.org/10.1101/468165 (2018).

30. Schmalhausen, I. I. Factors of Evolution: The Theory of Stabilizing Selection 327 (Blakiston Company, 1949).

31. Bull, J. J. Evolution of phenotypic variance. Evolution 41, 303-315. https://doi.org/10.1111/j.1558-5646.1987.tb05799.x (1987).

32. Williams, G. C. Natural Selection. Domains Levels and Challenges 53-103 ( Oxford University Press, 1992).

33. West-Eberhard, M. J. Developmental Plasticity and Evolution 794 (Oxford University Press, 2003).

34. Slatkin, M. Hedging one's evolutionary bets. Nature 250, 704705. https://doi.org/10.1038/250704b0 (1974).

35. Philippi, T. \& Seger, J. Hedging one's evolutionary bets, revisited. Trends Ecol. Evol. 4, 41-44. https://doi.org/10.1016/0169-5347(89) 90138-9 (1989).

36. Grafen, A. Formal Darwinism, the individual-as-maximising-agent analogy, and bet-hedging. Proc. R. Soc. Lond. Ser. B Biol. Sci. 266, 799-803. https://doi.org/10.1098/rspb.1999.0708 (1999).

37. Wade, B. S. \& Twitchett, R. J. Extinction, dwarfing and the Lilliput effect: Extinction, dwarfing and the Lilliput effect. Palaeogeogr. Palaeoclimatol. Palaeoecol. 284, 1-3. https://doi.org/10.1016/j.palaeo.2009.08.019 (2009).

38. Wade, B. S. et al. Taxonomy, biostratigraphy, and phylogeny of Oligocene and lower Miocene Dentoglobigerina and Globoquadrina. In Atlas of Oligocene Planktonic Foraminifera (eds Wade, B. S. et al.) Lawrence, KS, Cushman Foundation for Foraminiferal Research, Special Publication No. 46 (2018) 331-384.

39. Harvey, P. H. \& Pagel, M. D. The Comparative Method in Evolutionary Biology 35-49 (Oxford University Press, 1991).

40. O'Brien, C. L. et al. The enigma of Oligocene climate and global surface temperature evolution. Proc. Natl. Acad. Sci. 117, 2530225309. https://doi.org/10.1073/pnas.2003914117 (2020).

41. Stoecker, D. K., Johnson, M. D., De Vargas, C. \& Not, F. Acquired phototrophy in aquatic protists. Aquat. Microb. Ecol. 57, 279-310. https://doi.org/10.3354/ame01340 (2009).

42. Takagi, H. et al. Characterizing photosymbiosis in modern planktonic foraminifera. Biogeosciences 16, 3377-3396. https://doi.org/ 10.5194/bg-16-3377-2019 (2019).

43. Luciani, V., D’Onofrio, R., Dickens, G. R. \& Wade, B. S. Did photosymbiont bleaching lead to the Demise planktic foraminifer Morozovella at the Early Eocene climatic optimum. Paleoceanography 32, 1115-1136. https://doi.org/10.1002/2017PA003138 (2017).

44. Lutz, B. P. Low-latitude northern hemisphere oceanographic and climatic responses to early shoaling of the Central American Seaway. Stratigraphy 7, 151-176 (2010). 
45. Norris, R. D. Recognition and macroevolutionary significance of photosymbiosis in molluscs, corals, and foraminifera. Paleontol. Soc. Pap. 4, 68-100. https://doi.org/10.1017/S1089332600000401 (1998).

46. Ezard, T. H. G., Edgar, K. M. \& Hull, P. M. Environmental and biological controls on size-specific $\delta^{13} \mathrm{C}$ and $\delta^{18} \mathrm{O}$ in recent planktonic foraminifera. Paleoceanography 30, 151-173. https://doi.org/10.1002/2014PA002735 (2015).

47. Hughes, T. P. et al. Global warming transforms coral reef assemblages Nature 556, 492-496. https://doi.org/10.1038/s41586-0180041-2 (2018).

48. Schmidt, C., Heinz, P., Kucera, M. \& Uthicke, S. Temperature-induced stress leads to bleaching in larger benthic foraminifera hosting endosymbiotic diatoms. Limnol. Oceanogr. 56, 1587-1602. https://doi.org/10.4319/lo.2011.56.5.1587 (2011).

49. Spezzaferri, S., El Kateb, A., Pisapia, C. \& Hallock, P. In situ observations of foraminiferal bleaching in the Maldives, Indian Ocean. J. Foraminifer. Res. 48, 75-84. https://doi.org/10.2113/gsifr.48.1.75 (2018).

50. Heron, S. F., Maynard, J. A., van Hooidonk, R. \& Eakin, M. Warming trends and bleaching stress of the World's Coral Reefs 1985-2012. Sci. Rep. 6, 38402. https://doi.org/10.1038/srep38402 (2016).

51. Sully, S., Burkepile, D. E., Donovan, M. K., Hodgson, G. \& van Woesik, R. A global analysis of coral bleaching over the past two decades. Nat. Commun. 10, 1264. https://doi.org/10.1038/s41467-019-09238-2 (2019).

52. Brown, B. E. Coral bleaching: Causes and consequences. Coral Reefs 16, 129-138. https://doi.org/10.1007/s003380050249 (1997).

53. Saravanan, R., Ranjith, L., Jasmine, S. \& Joshi, K. K. Coral bleaching: Causes, consequences and mitigation. Mar. Fish. Inf. Serv. Tech. Extens. Ser. 231, 3-9 (2017).

54. Kucera, M. \& Darling, K. F. Cryptic species of planktonic foraminifera: Their effect on palaeoceanographic reconstructions . Proc. R. Soc Lond. Ser. A Math. Phys. Eng. Sci. 360, 695-718. https://doi.org/10.1098/rsta.2001.0962 (2002).

55. Weiner, A., Aurahs, R., Kurasawa, A., Kitazato, H. \& Kucera, M. Vertical niche partitioning between cryptic sibling species of a cosmopolitan marine planktonic protist. Mol. Ecol. 21, 4063-4073. https://doi.org/10.1111/j.1365-294X.2012.05686 (2012).

56. Matsui, H. et al. Changes in the depth habitat of the Oligocene planktic foraminifera (Dentoglobigerina venezuelana) induced by thermocline deepening in the eastern equatorial Pacific. Paleoceanography 31, 715-731. https://doi.org/10.1002/2016PA002950 (2016).

57. Morard, R., Reinelt, M., Chiessi, C. M., Groeneveld, J. \& Kucera, M. Tracing shifts in oceanic fronts using the cryptic diversity of the planktonic foraminifera Globorotalia inflata. Paleoceanography 31, 1193-1205. https://doi.org/10.1002/2016PA002977 (2016).

58. Morard, R. et al. Genetic and morphological divergence in the warm-water planktonic foraminifera genus Globigerinoides. PLoS ONE 14, 1-30. https://doi.org/10.1371/journal.pone.0225246 (2019).

59. Prasanna, K., Ghosh, P., Bhattacharya, S. K., Mohan, K. \& Anilkumar, N. Isotopic disequilibrium in Globigerina bulloides and carbon isotope response to productivity increase in Southern Ocean. Sci. Rep. 6, 21533. https://doi.org/10.1038/srep21533 (2016).

60. Waterson, A. M., Edgar, K. M., Schmidt, D. N. \& Valdes, P. J. Quantifying the stability of planktic foraminiferal physical niches between the Holocene and Last Glacial Maximum. Paleoceanography 32, 74-89. https://oi.org/10.1002/2016PA002964 (2017).

61. Andre, A. et al. Disconnection between genetic and morphological diversity in the planktonic foraminifer Neogloboquadrina pachyderma from the Indian sector of the Southern Ocean. Mar. Micropaleontol. 144, 1424. https://doi.org/10.1016/j.marmicro. 2018.10.001 (2018).

62. Schiebel, R. et al. Advances in planktonic foraminifer research: New perspectives for paleoceanography. Rev. Micropaléontol. 61, 113-138. https://doi.org/10.1016/j.revmic.2018.10.001 (2018).

63. Boscolo-Galazzo, F. et al. Temperature controls carbon cycling and biological evolution in the ocean twilight zone. Science 371, 1148-1152. https://doi.org/10.1126/science.abb6643 (2021).

64. Pälike, H. et al. Site 1338. Proceedings of the Integrated Ocean Drilling Program, vol 320/321. https://doi.org/10.2204/iodp.proc. 320321.101.2010 (2010).

65. Drury, A. J., Lee, G. P., Pennock, G. M. \& John, C. M. Data report: Late Miocene to early Pliocene coccolithophore andforaminiferal preservation at Site U1338 from scanning electron microscopy. In Proceedings of the Integrated Ocean Drilling Program, 320/321 (eds Pälike, H. et al.) https://doi.org/10.2204/iodp.proc.320321.218.2014 (Integrated Ocean Drilling Program Management International, Inc., Tokyo, 2014).

66. Fox, L. R. \& Wade, B. S. Systematic taxonomy of early-middle Miocene planktonic foraminifera from the Equatorial Pacific Ocean: Integrated Ocean Drilling Program, Site U1338. J. Foraminifer. Res. 43, 374-405. https://doi.org/10.2113/gsjfr.43.4.374 (2015).

67. Wade, B. S., Pearson, P. N., Berggren, W. A. \& Pälike, H. Review and revision of Cenozoic tropical planktonic foraminiferal biostratigraphy and calibration to the geomagnetic polarity and astronomical time scale. Earth Sci. Rev. 104, 111-142. https://doi. org/10.1016/j.earscirev.2010.09.003 (2011).

68. Kennett, J. P. \& Srinivasan, M. S. Neogene Planktonic Foraminifera: A Phylogenetic Atlas 1-265 (Hutchinson Ross Publishing Co., 1983).

69. Lyle, M., Joy Drury, A., Tian, J., Wilkens, R. \& Westerhold, T. Late Miocene to Holocene high-resolution eastern equatorial pacific carbonate records: Stratigraphy linked by dissolution and paleoproductivity. Clim. Past 15, 1715-1739. https://doi.org/10.5194/ cp-15-1715-2019 (2019).

70. Kotov, S. \& Pälike, H. QAnalySeries-A cross-platform time series tuning and analysis tool. AGU https://doi.org/10.1002/essoar. 10500226.1 (2018).

71. Brombacher, A., Wilson, P. A. \& Ezard, T. H. G. Calibration of the repeatability of foraminiferal test size and shape measures with recommendations for future use. Mar. Micropaleontol. 133, 21-27. https://doi.org/10.1016/j.marmicro.2017.05.003 (2017).

72. Brombacher, A., Elder, L. E., Hull, P. M., Wilson, P. A. \& Ezard, T. H. G. Calibration of test diameter and area as proxies for body size in the planktonic foraminifer Globoconella puncticulata. J. Foraminifer. Res. 48, 241-245. https://doi.org/10.2113/gsifr.48.3. 241 (2018).

73. Silverman, B. W. Density Estimation for Statistics and Data Analysis 176 (Chapman \& Hall/CRC, 1986).

74. R Core Team. R: A Language and Environment for Statistical Computing, R Foundation for Statistical Computing, Vienna, Austria http://www.R-project.org (2020).

75. Cohen, J. Statistical Power Analysis for the Behavioural Sciences (Lawrence Earlbaum Associates, 1988).

76. Champely, S. pwr: Basic Functions for Power Analysis. R package version 1.3-0 (2020) https://CRAN.R-project.org/package=pwr.

77. Edgar, K. M., Pälike, H. \& Wilson, P. A. Testing the impact of diagenesis on the $\delta 18 \mathrm{O}$ and $\delta 13 \mathrm{C}$ of benthic foraminiferal calcite from a sediment burial depth transect in the equatorial Pacific. Paleoceanography 28, 468-480. https://doi.org/10.1002/palo.20045 (2013).

78. Cramer, B. S., Toggweiler, J. R., Wright, J. D., Katz, M. E. \& Miller, K. G. Ocean overturning since the Late Cretaceous: Inferences from a new benthic foraminiferal isotope compilation. Paleoceanography https://doi.org/10.1029/2008PA001683 (2009).

79. Rasmussen, T. L. \& Thomsen, E. Holocene temperature and salinity variability of the Atlantic Water inflow to the Nordic seas. Holocene 20, 1223-1234. https://doi.org/10.1177/0959683610371996 (2010).

80. Shapiro, S. S. \& Wilk, M. B. An analysis of variance test for normality (complete samples). Biometrika 52, 591-611. https://doi. org/10.1093/biomet/52.3-4.591 (1965).

81. Komsta, L. outliers: Tests for outliers. R package version 0.14. https://CRAN.R-project.org/package=outliers (2011).

82. Fay, M. P. asht: Applied Statistical Hypothesis Tests. R package version 0.9.6. https://CRAN.R-project.org/package=asht (2020).

83. Arnholt, A. T. \& Evans, B. BSDA: Basic Statistics and Data Analysis. R package version 1.2.0. https://CRAN.R-project.org/packa ge=BSDA (2017). 


\section{Acknowledgements}

This research used samples provided by the International Ocean Discovery Program (IODP). This work was supported by the Natural Environmental Research Council (Studentship Grant NE/L002574/1) and the Yorkshire Geological Society Fearnsides Award. We would also like to extend our thanks to Paul Pearson, Paul Wignall, David Lazarus, and Martha Gibson for comments, and to Howard Spero for providing Carrera Marble standards, which were not used in these analyses. Finally, we would like to offer thanks to the reviewers, whose comments have greatly improved this manuscript.

\section{Author contributions}

A.W., S.L.J., R.A.J., and R.J.N. generated the data. All authors contributed to the interpretation of the data. A.W. plotted figures and wrote the R code to perform statistical analysis. A.W. and T.A. contributed to the writing and editing of the manuscript.

\section{Competing interests}

The authors declare no competing interests.

\section{Additional information}

Supplementary Information The online version contains supplementary material available at https://doi.org/ 10.1038/s41598-021-94140-5.

Correspondence and requests for materials should be addressed to A.W.

Reprints and permissions information is available at www.nature.com/reprints.

Publisher's note Springer Nature remains neutral with regard to jurisdictional claims in published maps and institutional affiliations.

(c) Open Access This article is licensed under a Creative Commons Attribution 4.0 International License, which permits use, sharing, adaptation, distribution and reproduction in any medium or format, as long as you give appropriate credit to the original author(s) and the source, provide a link to the Creative Commons licence, and indicate if changes were made. The images or other third party material in this article are included in the article's Creative Commons licence, unless indicated otherwise in a credit line to the material. If material is not included in the article's Creative Commons licence and your intended use is not permitted by statutory regulation or exceeds the permitted use, you will need to obtain permission directly from the copyright holder. To view a copy of this licence, visit http://creativecommons.org/licenses/by/4.0/.

(C) The Author(s) 2021 